\title{
KOMUNIKASI KEPEMIMPIN DALAM MENCARI RESOLUSI KONFLIK ANTAR GURU DI MTSN 3 LOMBOK TIMUR
}

\author{
ZOHRATUL HIDAYAH \\ STAI Darul Kamal NW Kembang Kerang Lotim NTB \\ zohratul@gmail.com
}

\begin{abstract}
ABSTRAK
Penelitian ini bertujuan untuk mengetahui proses komunikasi kepemimpinan yang di lakukan kepala sekolah dalam mencari resolusi konflik antar guru di MTSN 3 Lombok Timur. MTsN 3 LOTIM, adalah salah satu satuan pendidikan dengan jenjang MTs di BERIRI JARAK, Kec.Wanasaba, Kab. Lombok Timur, Nusa Tenggara Barat. Dalam menjalankan kegiatannya, MTsN 3 Lotim di bawah naungan kementerian agama. Metode pengumpulan data yang di gunakan adalah obsevasi, wawancara dan dokumentasi. Sumber informasi di dapatkan dari guru. penelitian ini menggunakan metode deskriptif dan di analisisi dengan pendekatan kualitatif, yang di sesuaikan dengan kodisi dan situasi di lapanagan. Hasil penelitian adalalah sebagai berikut : 1 . Pola komunikasi kepemimpinan dalam mencari resolusi konflik antar guru di MTsN 3 LOTIM, yaitu : Berdasarkan hasil dari wawancara, observasi dan dokumentasi bahwa komunikasi kepemimpinan dalam mencari resolusi konflik antar guru di MTsN 3 LOTIM memakai tiga pola (bentuk) komunikasi yaitu komunikasi interpersonal, komunikasi kelompok dan komunikasi organisasi. Dari hasil pengamatan yang peneliti lakukan bahwa sikap kepala sekolah MTsN 3 LOTIM dalam mengatasi konflik yaitu bersikap netral dan objetif, tidak membeda-bedakan antar guru, memberikan kesempatan kepada semua guru untuk menyampaikan pendapat dan selalu memotivasi guru dan memberi penghargaan bagi guru yang berprestasi. 2. Hambatan komunikasi kepemimpinan dalam mencari resolusi konflik antar guru di MTsN 3 LOTIM, Yaitu : Dari wawancara tersebut kendala yang di hadapi kepala sekolah dalam menyelesaikan konflik yaitu adanya perbedaan pendapat/pandangan, namun hal tersebut di anggap biasa saja/ hal yang wajar oleh kepla sekolah sehingga tidak terlalu di beratkan. 3. Solusi terhadap kendala yang dihadapi dalam komunikasi kepemimpinan dalam mencari resolusi konflik antar guru di MTsN 3 LOTIM, yaitu: Jadi setiap permasalahan yang ada kepala sekolah selalu melaukan diskusi dan musayawarah sehingga permasalaha yang terjadi langsung di tangani tanapa harus di tunda-tunda menunggu waktu yang tepat.
\end{abstract}

Kata kunci: komunikasi, kepemimpinan, resolusi konflik 


\section{A. LATAR BELAKANG}

Komunikasi merupakan sebuah proses sosial yang sangat mendasar dalam kehiduapan manusia, karena setiap orang dalam kehidupanya sesalu berkeinginan untuk mempertahankan suatu persetujuan mengenai berbagai anturan sosial melalui komunikasi. Komunikasi berlangsung untuk menjalin hubungan antar individu, individu dengan kelompok dan kelompok dengan kelompok.

Komunikasi adalah proses penyampaian atau penerimaan pesan dari satu orang kepada ornag lain, baik langsung maupun tidak langsung, secara tertulis, lisan, maupun bahasa non verbal. ${ }^{1}$ komunikasi juga dapat di artikan sebagai " proses dimana suatu ide dialihkan dari sumber kepada satu penerima atau lebih, dengan makdud untuk mengubah tingkah laku mereka. $^{2}$

Bahwa komunikasi adalah kegiatan penyampaian pesan dari satu orang kepada orang lain baik individu maupun kelompok yang di lakukan secara langsung maupun tidak langsung, secara verbal atau nonverbal deng tujuan untuk mempengatuhi tinkah laku lawan bicara kita.

Pemimpin yang efektif harus bisa memberikan arahan, evaluasi dan koreksi terhadap usaha-usaha yang di lakukan oleh anggota dalam mencapai tujuan. Di dalam organisasi/ lembaga pendidikan manapun tidak akan mencapai tujuan apabila di dalanya tidak terjalin komunikasi yang baik antara pemimpin dan bawahanya maupun sebaliknya. Hubungan yang harmonis di antara para anggota di sebabakan oleh komunikasi timbal balik yang baik.

Kepemimpinan dan bentuk komunikasi memiliki peran yang sangat penting dalam mencapai tujuan organisasi. Kepemimpinan dapat di artikan sebagai kemampuan seseorang untuk mempengaruhi,menggerakkan,memotivasi, mengkoordiasi dan mengarahkan bawahan sehingga mau bekerja untuk mencapai tujuan bersama yang telah di tetapkan.

Dalam kehiduapan berorganisasi pasti tidak akan lepas dari pada konflik. Konflik tidak bisa dihindari dan mempunyai fungsipositif di samping dapat menyebabkan disfungsional.pada dasarnya konfik merupakan proses batin yang meliputi kegelisahan karena adnya pertentangan atara kedua belah pihak atau lebih.

Dalam hal ini sekolah merupakan salah satubentuk dari organisasi yang di dalamnya terdapat kumpulan individu,dengan karakter dan latar belakang yang berbeda. Dengan sendirinya akan akan meninbulkan sebuah konflik dalam organisasi sekolah tersebut. oleh karena itu komunikasi kepemimpinan yang efektif sangat di butuhkan.

Dengan demikian di dalam penelitian ini penulis akan melakukan penelitian tentang komunikasi kepemimpinan dalam mencari resolusi konflik antar guru di MTSN 3 Lombok Timur, Kecamatan Wanasaba. Salah satu sekolah menengah tingkat pertama, MTSN 3 LOTIM termasuk sekolah pavorit di kecamatan wanasaba, meskipun lokasi sekolah ini jauh

\footnotetext{
${ }^{1}$ Husaini Usman, Manajmen: Teori,Praktik Dan Riset Pendidikan. ( Jakarta : Bumi Aksara, 2014),Hlm. 470.
}

${ }^{2}$ Dedi Mulyana, Ilmu Komunikasi Suatu Pengantar. ( Bandung : Remaja Rosdakrya,2001) 
dari permukiman masyarakat namunn sekolah ini banyak di minati oleh murid karena di sekolah MTSN 3 LOTIM sangat menunjang proses belajar mengajar. selain itu MTSN 3 LOTIM juga mempunyai guru-guru yang profesional, dan input siswa unggul, dan di dukung oleh fasilitas dan sarana prasarana yang memadai atau lengkap yang ada di sekolah. Salah satu fasilitas dan sarana prasaranayang di miliki sekolah tersebut adalah perpustakaan dan lainya.

\section{B. PEMBAHASAN}

\section{Kajian Teori}

\section{Komunikasi kepemimpinan}

a. Pengertian komunikasai kepemimpinan

Istilah komunikasi dalam bahasa inggris comunication berasal dari baahasa latin communication, dan bersumber dari kata cmmunis yang berrati sama. Hal yang sama di ungkapkan oleh hafied cangara, komunikasi berpangkl pada perkataan latin communis yang artinya membuat kebersaman atau membangun kebersamaan antar dua orang atau lebih

Kepemimpinan

Kepemipinan menjadi sangat pentingkarena dalm kepemimpinan yang baik dan efektif akan membangun,mendorong organisasi dalam mencapai kesuksesan. Pemimpin adalah seorang yang memilki kemampuan untuk mempengaruhi dan mengarahkan orang lain untuk mengikuti arahan aktivitas dan tindakannya demi mencapai tujuan.

b. Pola-pola komunikasi

Susanto menyatakan bahwa ada lima konteks komunikasi yaitu: komunikasi interpersonal, komunikasi antar personal, komunikasi kelompk, komunikasi organisasi dan komunikasi massa.

Komunikasi interpersonal merupakan proses komunikasi yang terjadi dalam diri seseorang yang di lakukan dengan sengaja atau tidak sengaja. komunikasi kelompok menitik beratkan pada interaksi antara orang orang-orang dalam kelompok kecil, yang terdiri dari beberapa orang yang bekerja untuk mencapai tujuan bersama. Komikaso organisasi menurut wiryanto ( dalam khomasarial romli,2011) adalah pengiriman dan penerimaan berbagai pesan organisasi di dalm kelompok formal maupun informal dari suatu organisasi. Komunikasi massa merupakan peroses menciptakan makna yang sama diantara media massa dan para komunikasi.

2. Konflik

a. Pengertian konflik

Konflik merupakan gejala sosial dalam kehidupan sosial,konflik akan senantiasa ada dalam setiap ruang dan waktu, dimana saja dan kapan saja. Istilahkonflik secara etimologi berasal dari bahasa latin con yang berati bersama fligere yang berti benturan atau tabrakan. Pada umumnya istilah konflik sosial 
mengandungsuatu rangkaian pertentangan dan pertikaian antar pribadi mulaikonflik kelas sampai pada pertentangan danpeperangan internasional.

b. Faktor-faktor penyebab terjadinya konflik

Yaitu perbedaan pendirian dan kenyakinan oang perorang menyebabkan konflik antar individu; perbedaan kebudayaan, dan perbedaan kepentingan.

c. Resolusi konflik

Konflik harus diatasi, jangan sampai berlarut-larut karena yang dirugikan tidak hanya individu tetapi juga lembaga. Proses pembelajaran bisa terganggu dan kepuasan anak didik jauh dari harapan. Manajer dan pemimpin pendidikan harus cepat membaca potensi konflik, mengantisipasi konflik muncul ke permukaan atau melebar, dan selalu menciptakan langkah-langkah seefektif mungkin.

Dalam menyelesaikan konflik, terdapat lima langkah meraih kedamaian dalam konflik.

1.Pengenalan;

2. Diagnosis

3. Menyepakati suatu solusi

4. Pelaksanaan dan

5. Evaluasi.

Strategi mengatasi konflik intrapersonal dan intragrup (intrapersonal and intragroup conflict) adalah dengan: Menciptakan kontak dan membina hubungan sahabat, pertemanan, dan jalinan hubungan yang erat untuk menciptakan kontak batin yang baik pula. Dengan menciptakan kontak tersebut, maka setiap individu akan saling memahami dirinya sendiri dan satu sama lain secara mendalam. Menumbuhkan rasa percaya dan penerimaan. Hal ini penting karena setiap orang butuh pengakuan dari orang lain serta apa yang dilakukannya, yang dikatakannya, dan disarankannya butuh penerimaan dari orang lain sebagai tenggang rasa dan penghargaan terhadap dirinya. Menumbuhkan kekuatan dan kemampuan diri sendiri. Hal ini juag penting karena dengan menumbuhkan kekuatan diri berarti seseorang sudah kokoh dan tangguh dalam mengahadapi setiap cobaan dan ujian, dan dengan menumbuhkan kemampuan diri sebagai power dan bekal dalam menghadapi permasalahan

Strategi mengatasi konflik interpersonal dan intergroup (Interpersonal and Intergroup Conflict) adalah dengan:

Strategi Kalah-Kalah (Lose-lose Strategy); berorientasi pada dua individu atau kelompok yang sama-sama kalah. Biasanya individu atau kelompok yang bertikai mengambil jalan tengah (berkompromi) atau membayar sekelompok orang yang terlibat dalam konflik atau menggunakan jasa orang atau kelompok ketiga sebagai penengah. Dalam strategi kalah-kalah, konflik bisa diselesaikan 
dengan cara melibatkan pihak ketiga bila perundingan mengalami jalan buntu. Maka pihak ketiga diundang untuk campur tangan oleh pihak-pihak yang berselisih atau barangkali bertindak atas kemauannya sendiri.

Hasil kalah-kalah biasanya terjadi apabila konflik dimanaje dengan sikap menghindari, akomodasi, meratakan dan atau melalui kompromi. Ada dua tipe utama dalam campur tangan pihak ketiga yaitu:
a. Arbitrase (Arbitration)
b. Mediasi (Mediation)

Strategi Menang-Kalah (Win-Lose Strategy); Dalam strategi ini menekankan adanya salah satu pihak yang sedang konflik mengalami kekalahan tetapi yang lain memperoleh kemenangan. Beberapa cara yang digunakan untuk menyelesaikan konflik dengan win-lose strategy adalah sebagai berikut:
a. Penarikan diri,
b. Taktik-taktik penghalusan dan damai,
c. Bujukan,
d. Taktik paksaan dan penekanan,
e. Taktik-taktik yang berorientasi pada tawar-menawar dan pertukaran persetujuan sehingga tercapai suatu kompromi yang dapat diterima oleh dua belah pihak,

Strategi Menang-Menang (Win-Win Strategy); Konflik menang-menang diatasi dengan jalan menguntungkan semua pihak yang terlibat dalam konflik yang bersangkutan. Ada 2 cara didalam strategi ini yang dapat dipergunakan sebagai alternatif pemecahan konflik menang- menang yaitu:

a. Pemecahan Masalah Terpadu (Integrative Problema Solving). Usaha untuk menyelesaikan secara mufakat atau memadukan kebutuhan- kebutuhan kedua belah pihak

b. Konsultasi Proses antar Pihak (Inter- Party Process Consultation) ${ }^{3}$

3. Komunikasi Kepemimpinan Dalam Penyelesaian Konflik

Terkait dengan kepemimpinan maka komunikasi yang baik sangatlah penting di miliki oleh seorang pemimpin karena berkaitan dengan tugasnya yaitu untuk mempengaruhi, mengarahkan, membimbing,dan memotivasi anggota untuk melakukan aktivitas untuk mencapai tujuan yang telah di tetapkan serta mencapai efektivitas dalam kepemimpinan. Jika seoarang pemimpin tidak mampu

${ }^{3}$ Sunarta. (2011). Konflik dalam organisasi (merugikan sekaligus menguntungkan), Artikel Berkala FISE Universitas Negeri Yogyakarta. 
berkomunikasi dengan baik kepada bawahanya otomatis aktivitas dalam dalam mencapai tujuan tidak akan berjan dengan baik. Dan tidak akan mungkin komunikasi berjalan dengan baik jika seorang pemimpin tidak memberikan kenyamanan, malahan yang ada bawahan akan ketakutan dalam menyampaikan informasi kepadanya.

Adapun kecakapan komunikasi yang mengembangkan pengelolaan konflik yaitu ${ }^{4}$ :

1. Kecakapan berkomunikasi untuk memprakarsai konflik

2. Kecakapan berkomunikasi untuk merespon konlik; dan

3. Kemampuan berkomunikasi untuk menengahi konflik

\section{METODE PENELITIAN}

Penelitian di laksannakan di MTSN 3 Lombok Timur, dengan tujuan untuk mengetahui bagaimana proses komunikasi kepemimpinan yang di lakukan kepala sekolah MTSN 3 LOTIM dalam mencari resolusi konflik antar guru. Waktu penelitian, penulis melakukan penelitian pada hari sabtu, 15 januari 2022, sekitar jam 9 lebih.

penelitian ini menggunakan metode deskriptif dan di analisisi dengan pendekatan kualitatif, yang di sesuaikan dengan kodisi dan situasi di lapanagan. Sumber data dari penelitian ini yaitu kepala sekolah dan guru.

Teknik pengumpulan data yang di gunakan dalam penelitian ini adalah observasi; langsung kelokasi sekolah,wawancara; dengan menanyakan beberapa pertanyaan dan dokumentasi berupa rekaman dan foto ${ }^{5}$.

\section{PENYAJIAN HASIL PENELITIAN}

Pada baian ini akan di jelaskan dari penelitian yang di lakukan dengan berbagai permasalahan yang di peroleh peneliti di lapangan. Data penelitian mengenai komunikasi kepemimipinan dalam mencari resolusi konflik di MTsN 3 LOTIM, di peroleh penelitian dengan menggunakan observasi, wawancara, dan dokumentasi. Subjek yangmenjadi sumber informasi penelitian ini yaitu yang seharusnya kepala sekolah, namun pada hari itu kepala sekolah sedang melakukan rapat yang tidak bisa di tinggalkan, sehingga kepla sekolah menugaskan guru bagian kurikulum untuk melayani kami, penulis kelokasi penelitian tidak sendiri melainkan dengan beberapa teman yang memiliki judul penelitian yang berbeda-beda. Dan kami melakukan wawancara dengan guru bagian kurikulum. Berikut ini disajikan hasil penelitian yang di peroleh peneliti.

\section{Pola komunikasi kepemimpinan dalam mencari resolusi konflik antar guru di MTsN 3 LOTIM}

${ }^{4}$ Wirawan. (2010). Konflik dan manajemen konflik. Jakarta: Salemba Humanika

${ }^{5}$ Sutopo, Heribertus. 2002. Metodologi Penelitian Kualitatif. Surakarta: UNS Press. 
Untuk mengetahui bagaimana pola komunikasi kepemimpinan dalam mencariresolusi konflik antar guru di MTsN 3 LOTIM peneliti mengajukan beberapa pertanyaan yang telah di persiapkan hasil wawancaranya yaitu :

Peneliti : bagaimana sikap bapak dalam mengatasi jika terjadi konflik antar guru?

Guru/pak Fathurrahman : 1. untuk mengatasi konflik antar guru jadi kepala sekolah berusaha netral dan objektif tidak membeda-bedakan satu guru dengan guru ynag lain, peran kepala sekolah dari sisi manajerial benar-benar jadi bapak bagi semua guru. 2 . Memberikan kesempatan kepada semua guru/tenaga kependidikan untuk menyampaikan pendapatnya. 3. Sisi peran manajerial kepala sekolah juga aktif memberikan motivasi kepada guru-guru artinya guru yang berprestasi di berikan reward dalam bentuk ucapan terimakasih dan penghargaan-penghargaan.

Dari hasil pengamatan yang peneliti lakukan bahwa sikap kepala sekolah MTsN 3 LOTIM dalam mengatasi konflik yaitu bersikap netral dan objetif, tidak membedabedakan antar guru, memberikan kesempatan kepada semua guru untuk menyampaikan pendapat dan selalu memotivasi guru dan memberi penghargaan bagi guru yang berprestasi.

Berdasarkan hasil dari wawancara, observasi dan dokumentasi bahwa komunikasi kepemimpinan dalam mencari resolusi konflik antar guru di MTsN 3 LOTIM memakai tiga pola (bentuk) komunikasi yaitu komunikasi interpersonal, komunikasi kelompok dan komunikasi organisasi. Dimana ketiga pola komunikasi tersebut di gunkan di lihat dari jawaban dari guru tersebut/ di lihat dari hasil wawancara, dimana pemimpin melibatkan semua dalam menyampaikan pendapat dalam mencari resolusi permasalahan dan melakukan diskusi atau musyawararah.

\section{Hambatan Komunikasi Kepemimpinan dalam mencari resolusi konflik antar guru} di MTsN 3 LOTIM

Adapun pertanyaan-nya yaitu:

Peneliti : apa saja kendala yang bapak hadapi dalam mencari resolusi konflik yang terjadi antar guru tersebut

Guru/pak Fathurrahman : tidak ada masalah/kendala yang terlalu signifikan, hanya saja ada perbedaan pandangan, distribusi jam pelajaran dan lainya. Kepala sekolah sudah mengatur semuanya, semua warga madrasah di berikan kesempatan untuk memenuhi yang yang terkait dengan hak-haknya misalanya ada guru yang baru sertifikasi tetap diberikan hak mengajarnya itu untuk memenuhi kewajiban agar hak-haknya bisa terbayar dari negara, karena prinsip selama ini tidak ada kesulitan yang terlalu signifikan.

Dari wawancara tersebut kendala yang di hadapi kepala sekolah dalam menyelesaikan konflik yaitu adanya perbedaan pendapat/pandangan, namun hal tersebut di anggap biasa saja/ hal yang wajar oleh kepla sekolah sehingga tidak terlalu di beratkan.

Penyebab dari konflik yang sering terjadi di MTsN 3 LOTIM yaitu konflik dalam konteks kesenjanagan antara yang PNS dan yang tidak PNS, pemenuhan jam 
belajar. Karena di madrasah negeri ini ada skala prioritas di pembagian tugas di prioritaskan ada pegawai negeri yang sudah di setifikasi di penuhi dulu haknya baru guru yang tidak sertifikasi terus guru honor sertifikasi dan guru tidak sertifikasi.

3. Solusi Terhadap Hambatan Komunikasi Kepemimpinan dalam mencari resolusi Konflik Antar Guru di MTsN 3 LOTIM

Dalam mengatasi hambatan-hambatan yang mucul terhadap komunikasi kepemimpinan dalam penyelesaian konflik antar guru di MTsN 3 LOTIM tentunya kepala madrasah memilki cara tersendiri dalam mengatasi hambatan tersebut demi meminimalisir dampak negatif yang ditimbulkan dari permasalahan tersebut.Adapun pertanyaan yang peneliti ajukan kepada kepala MTsN 3 LOTIM, yaitu:

Peneliti : bagaimana cara bapak mengatasi kendala yang terjadi dalam penyelesaian konflik antar guru di MTsN 3 LOTIM ?

Guru/pak Fathurrahman : jika terjadi permasalahan seperti di atas, seperti perbedaan pandangan, maka cara kepala sekolah mengatasi kendala sertebut dengan cara di diskusikan, di panggil satu pihak dan pihak lainnya, apa permasalahannya kemudian didiskusikan bersama, berusaha mencari tititk temu, memeberikan win-win solution. Namun secara konflik pribadi antar guru tidak ada hanya saja ada distribusi jam belajar, perbedaan-perbedaan paradigma mendidik karea rata-rata pendidik maka setiap permasalahan yang ada berakhir di ruang-ruang diskusi atau musyawarah.

Jadi setiap permasalahan yang ada kepala sekolah selalu melaukan diskusi dan musayawarah sehingga permasalaha yang terjadi langsung di tangani tanapa harus di tunda-tunda menunggu waktu yang tepat.

\section{C.PENUTUP}

\section{Kesimpulan}

Dari hasil penelitian yang lakukan, maka dapat ditarik beberapa kesimpulan sebagai berikut:

1. Pola komunikasi kepemimpinan dalam mencari resolusi konflik antar guru di MTsN 3 LOTIM, yaitu : Berdasarkan hasil dari wawancara, observasi dan dokumentasi bahwa komunikasi kepemimpinan dalam mencari resolusi konflik antar guru di MTsN 3 LOTIM memakai tiga pola (bentuk) komunikasi yaitu komunikasi interpersonal, komunikasi kelompok dan komunikasi organisasi. Dari hasil pengamatan yang peneliti lakukan bahwa sikap kepala sekolah MTsN 3 LOTIM dalam mengatasi konflik yaitu bersikap netral dan objetif, tidak membeda-bedakan antar guru, memberikan kesempatan kepada semua guru untuk menyampaikan pendapat dan selalu memotivasi guru dan memberi penghargaan bagi guru yang berprestasi.

2. Hambatan komunikasi kepemimpinan dalam mencari resolusi konflik antar guru di MTsN 3 LOTIM, Yaitu : Dari wawancara tersebut kendala yang di hadapi kepala sekolah dalam menyelesaikan konflik yaitu adanya perbedaan pendapat/pandangan, 
namun hal tersebut di anggap biasa saja/ hal yang wajar oleh kepla sekolah sehingga tidak terlalu di beratkan.

3. Solusi terhadap kendala yang dihadapi dalam komunikasi kepemimpinan dalam mencari resolusi konflik antar guru di MTsN 3 LOTIM, yaitu: Jadi setiap permasalahan yang ada kepala sekolah selalu melaukan diskusi dan musayawarah sehingga permasalaha yang terjadi langsung di tangani tanapa harus di tunda-tunda menunggu waktu yang tepat.

\section{Saran}

1. Diharapkan kepada kepala MTsN 3LOTIM untuk terus berusaha membina proses komunikasi yang terjalalin dengan baik antar guru di MTsN 3 lotim agar tidak timbulnya lagi konflik-konflik lainnya dan terus memeberikan motivasi-motivasi agar semua guru atau staf lebih bersemangat dalam bekerja.

2. Semoga dengan adanya artikel penelitian ini bisa menambah wawasan atau pengetahuan kitakhususnya mengenai penelitian ini, dan penulis sangat menyadari bahwa dalam artikel penulis ini masih terdapat banyak kesalhan dan kekurangan,untuk itu penulis mohon kritik dan saran yang membangun dari para pembaca sangat kami harapkan demi ksempurnaan artikel penelitian selanjutnya. Semoga artikel ini bisa bermanfaat bagi kita semua. 


\section{DAFTAR PUSTAKA}

Husaini Usman, Manajmen: Teori,Praktik Dan Riset Pendidikan. ( Jakarta : Bumi Aksara, 2014),Hlm. 470.

Dedi Mulyana, Ilmu Komunikasi Suatu Pengantar. ( Bandung : Remaja Rosdakrya,2001)

Sunarta. (2011). Konflik dalam organisasi (merugikan sekaligus menguntungkan), Artikel Berkala FISE Universitas Negeri Yogyakarta.

Sutopo, Heribertus. 2002. Metodologi Penelitian Kualitatif. Surakarta: UNS Press.

Winardi. (2004). Manajemen konflik (konflik perubahan dan pengembangan. Bandung: CV Mandar Maju.

Wirawan. (2010). Konflik dan manajemen konflik. Jakarta: Salemba Humanika 